\title{
PREIMPLANTATION DEVELOPMENT IN VIVO AND IN VITRO IN BANK VOLES, CLETHRIONOMYS GLAREOLUS, TREATED WITH PMSG AND HCG
}

\author{
EWA T. MYSTKOWSKA \\ Laboratory of Experimental Embryology, Institute of Obstetrics and Gynaecology, \\ Medical Academy, Warsaw, Poland
}

(Received 17th Fune 1974)

\begin{abstract}
Summary. Ovulation can be induced in the bank vole by PMSG and HCG and takes place $9 \frac{1}{2}$ to $11 \frac{1}{2} \mathrm{hr}$ after administration of HCG. The number of eggs obtained varied from 1 to 30 (average 9.3). The highest ovulation rates were observed when PMSG and HCG were administered 41 to $43 \frac{1}{2} \mathrm{hr}$ apart. The embryos attained the blastocyst stage $96 \mathrm{hr}$ after HCG injection. Bank vole eggs can be cultured in chemically defined media beginning with the eight-cell stage; only $25 \%$ of fourcell eggs developed to blastocysts in vitro.
\end{abstract}

\section{INTRODUCTION}

Although the bank vole is bred in several laboratories (see Festing, 1971), very little is known about the reproduction and embryonic development of this species (Brambell \& Rowlands, 1936; Clarke, Clulow \& Grieg, 1970).

The aim of the present studies was threefold: first, to investigate the ability of gonadotrophins (PMSG and HCG) to cause ovulation; second, to develop a method of culturing cleaving eggs; and third, to collect data on the rate of preimplantation development in vivo and in vitro.

\section{MATERIALS AND METHODS}

The animals used in the present study were obtained from the Mammals Research Institute in Białowieża. For the duration of the experiments (2 to 5 months), females were kept in groups of five to eight in cages measuring $30 \times$ $20 \times 14 \mathrm{~cm}$, and males were kept singly. The lighting regimen was 13 to $14 \mathrm{hr}$ light/24 hr (lights from 07.00 hours) and the room temperature varied from 17 to $20^{\circ} \mathrm{C}$. Food was provided in excess once daily and consisted of seeds, red beet, carrot and specially granulated food for rabbits.

Induction of ovulation with PMSG and HCG

Females were given an intraperitoneal injection of 5 i.u. PMSG (Gestyl: Organon) followed by intraperitoneal administration of 5 i.u. HCG (Biogonadyl: Biomed) 35 to $50 \mathrm{hr}$ later. The PMSG injection was given at various times between 06.00 and 23.00 hours. Immediately after the second injection, 
the females were caged with males and inspected for the presence of a vaginal plug $4 \frac{1}{2}$ to $12 \mathrm{hr}$ later. The animals were killed $8 \frac{1}{2}$ to $96 \mathrm{hr}$ after the injection of HCG and the embryos were flushed from the oviduct or the uterus with Ringer solution supplemented with bovine plasma albumin. Females that did not mate were not given another hormonal treatment for at least 14 days. Twelve females, which were not placed with males, were killed at 30-min intervals from $8 \frac{1}{2}$ to $14 \mathrm{hr}$ after the administration of HCG.

\section{Development in vivo}

The ages of embryos flushed from the oviducts and uteri were expressed as the time from the HCG injection (Table 2), but the real age of embryos could be determined from the time of ovulation, i.e. $9 \frac{1}{2}$ to $11 \frac{1}{2} \mathrm{hr}$ after the HCG injection. The number of cells in embryos aged $64 \mathrm{hr}$ or more was determined on airdried preparations made by the technique of Tarkowski (1966).

\section{Development in vitro}

The embryos were cultured in Whitten's medium (Whitten, 1971) and in the medium devised by J. G. Mulnard (personal communication). The composition of Mulnard's medium is as follows (in $\mathrm{mg} / 100 \mathrm{ml}$ ): $\mathrm{NaCl}, 757 ; \mathrm{KCl}, 35$; $\mathrm{MgSO}_{4} .7 \mathrm{H}_{2} \mathrm{O}, 29 ; \mathrm{NaH}_{2} \mathrm{PO}_{4} \cdot \mathrm{H}_{2} \mathrm{O}, 16$; calcium lactate. $5 \mathrm{H}_{2} \mathrm{O}, 71$; glucose, 83; sodium pyruvate, 3 ; phenol red, 2 ; $\mathrm{NaHCO}_{3}, 100$; bovine plasma albumin, fraction $V_{1}, 300$; streptomycin, 5 ; penicillin, 7.5. In some experiments, this medium was slightly modified and contained $140 \mathrm{mg} \mathrm{NaHCO}$ and $727 \mathrm{mg}$ $\mathrm{NaCl} / 100 \mathrm{ml}$. The eggs were cultured in drops of medium under liquid paraffin (Tarkowski, 1961; Brinster, 1963). The following gas mixtures were used: exhalated air; $3 \% \mathrm{CO}_{2}$ in air; $6.2 \% \mathrm{CO}_{2}$ in air; and $3 \% \mathrm{CO}_{2}, 5 \% \mathrm{O}_{2}$ and $92 \% \mathrm{~N}_{2}$.

\section{RESULTS}

\section{Induction of ovulation}

The highest average number of eggs was obtained when PMSG and HCG were given 41 to $43 \frac{1}{2} \mathrm{hr}$ apart (Table 1).

Of the 236 females which were given PMSG and HCG, $122(51.7 \%)$ mated. Among ninety-eight females which had mated and which were subsequently killed, no eggs could be found in the oviducts of eight $(8.2 \%)$ and all the eggs were unfertilized in another four (4.0\%). Of the 796 eggs obtained from the remaining eighty-six females, there were 664 developing eggs (an average of $7 \cdot 7$ embryos/female), fifty-one unfertilized eggs and eighty-one degenerated eggs. The number of eggs in individual females varied from one to thirty (Textfig. 1).

Development beyond implantation may occur after hormonally induced ovulation and mating. Three females left until term gave birth to two, five and nine young, respectively, but only four of sixteen females killed between the 5 th and 9 th day of pregnancy had implanted embryos (mean $=4 \cdot 2 /$ female).

In the females treated with PMSG and HCG but not placed with a male, two killed $8 \frac{1}{2}$ and $9 \mathrm{hr}$ after the HCG injection had not ovulated. Two females killed after $9 \frac{1}{2}$ and $10 \mathrm{hr}$ had seven and four eggs in only one oviduct, and three 
Table 1. The relationship between the number of eggs ovulated in voles and the interval between PMSG and HCG

\begin{tabular}{l|cccccc}
\hline & \multicolumn{7}{|c}{ Interval between injections of $P M S G$ and HCG (hr) } \\
& 35 to & 38 to & 41 to & 44 to & 47 to & 50 to \\
& $37 \frac{1}{2}$ & $40 \frac{1}{2}$ & $43 \frac{1}{2}$ & $46 \frac{1}{2}$ & $49 \frac{1}{2}$ & $52 \frac{1}{2}$ \\
\hline No. of females & 5 & 6 & 31 & 22 & 20 & 2 \\
Total no. of ova & 44 & 41 & 291 & 164 & 114 & 9 \\
Mean no. of ova/female & 8.8 & 6.8 & 9.4 & 7.5 & 5.7 & 4.5 \\
\hline
\end{tabular}

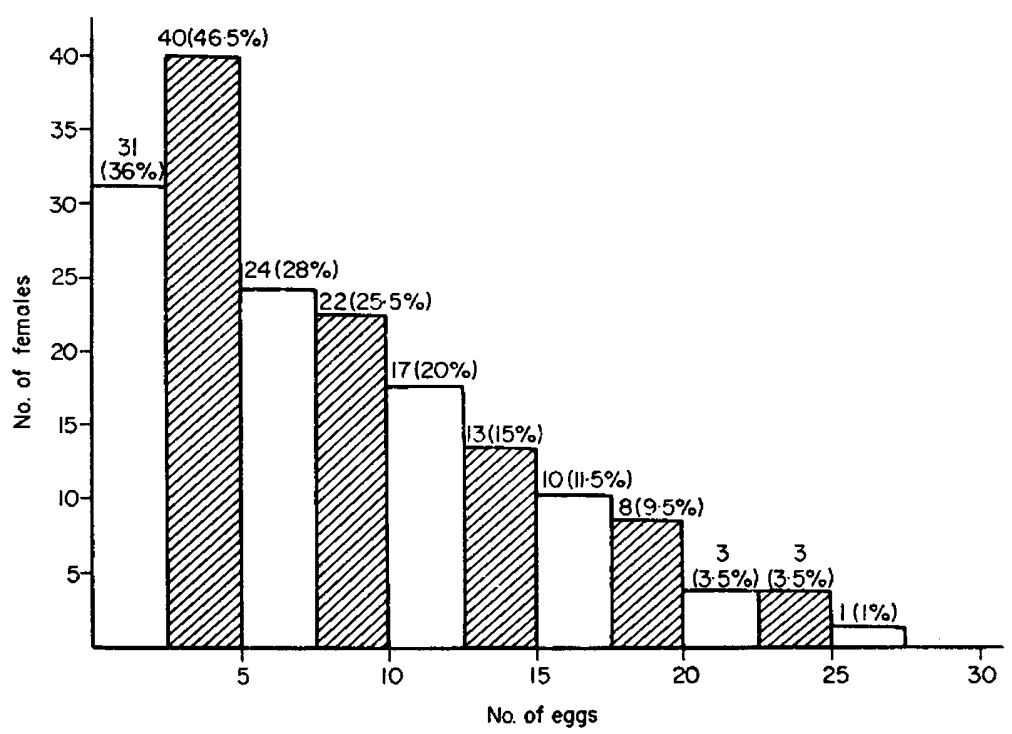

TEXT-PIG. 1. The number of ovulated eggs (open columns) and developing eggs (hatched columns) in bank voles after treatment with PMSG and HCG.

Table 2. Rate of development of bank vole eggs in vivo

\begin{tabular}{|c|c|c|c|c|c|c|c|c|c|c|c|}
\hline $\begin{array}{l}\text { Time after } H C G \\
\text { injection (hr) }\end{array}$ & $\begin{array}{c}\text { Total no. } \\
\text { of eggs }\end{array}$ & 1 & 2 & 3 & $\begin{array}{c}\text { Noo } \\
4\end{array}$ & $\begin{array}{l}\text { of blastc } \\
4 \text { to } 8\end{array}$ & $\begin{array}{l}\text { ieres } \\
8\end{array}$ & 8 to 16 & 16 & $>16$ & $\begin{array}{c}\text { Blasto } \\
\text { cysts }\end{array}$ \\
\hline $\begin{array}{l}24 \text { to } 26 \\
28 \text { to } 30 \\
42 \text { to } 46 \\
49 \text { to } 49 \cdot 3 \\
50 \text { to } 51 \cdot 3 \\
52 \text { to } 54 \cdot 3 \\
55 \text { to } 58 \\
60 \text { to } 61 \\
64 \text { to } 66 \\
67 \text { to } 68 \\
69 \text { to } 70 \\
71 \text { to } 72 \\
96\end{array}$ & $\begin{array}{r}41 \\
29 \\
23 \\
6 \\
73 \\
28 \\
46 \\
26 \\
15 \\
13 \\
27 \\
26 \\
14\end{array}$ & $\begin{array}{c}41 \\
1 \\
: \\
: \\
: \\
: \\
: \\
: \\
:\end{array}$ & $\begin{array}{r}28 \\
20 \\
1 \\
1 \\
. \\
. \\
. \\
i \\
. \\
. \\
.\end{array}$ & $\begin{array}{l}\text { i } \\
. \\
\dot{0} \\
\dot{0}\end{array}$ & $\begin{array}{r}2 \\
3 \\
62 \\
2 \\
17 \\
9 \\
. \\
. \\
\\
\end{array}$ & $\begin{array}{l}3 \\
4 \\
3 \\
1 \\
\mathrm{i} \\
.\end{array}$ & $\begin{array}{r}22 \\
25 \\
13 \\
7 \\
3 \\
. \\
.\end{array}$ & $\begin{array}{r}: \\
: \\
: \\
: \\
: \\
7 \\
1 \\
10 \\
4 \\
\cdot\end{array}$ & $\begin{array}{r}: \\
: \\
: \\
: \\
: \\
. \\
8 \\
10 \\
.\end{array}$ & $\begin{array}{l}\dot{ } \\
\dot{5} \\
\dot{5} \\
\dot{0} \\
\dot{6} \\
\dot{8}\end{array}$ & $\begin{array}{l}: \\
: \\
: \\
: \\
: \\
: \\
: \\
\dot{14}\end{array}$ \\
\hline
\end{tabular}


females killed between $10 \frac{1}{2}$ and $11 \frac{1}{2} \mathrm{hr}$ had seventeen, fifteen and nineteen eggs. Two of five females killed between $11 \frac{1}{2}$ and $14 \mathrm{hr}$ had twenty and twelve eggs; no eggs could be found in the oviducts of the other three animals. It seems, therefore, that ovulation starts about $9 \frac{1}{2} \mathrm{hr}$ and is completed by $11 \frac{1}{2} \mathrm{hr}$ after the injection of HCG.

\section{Development in vivo}

As shown in Table 2, embryos were in the one-cell stage up to $26 \mathrm{hr}$ after HCG treatment. The first cleavage occurred between the 26th and 28th hr. The second cleavage took place between the 45 th and $50 \mathrm{th} \mathrm{hr}$. Some embryos reached the eight-cell stage between 58 and $61 \mathrm{hr}$ but after $64 \mathrm{hr}$ the rate of development of individual embryos varied considerably, e.g. the embryos recovered from one female $69 \mathrm{hr}$ after the HCG injection consisted of seven to sixteen blastomeres. After $96 \mathrm{hr}$, blastocysts were found in the uterus and each consisted on average of 49.4 cells including 2.5 metaphase plates (mean from fourteen blastocysts).

Table 3. Culture of four- and eight-cell bank vole eggs in vitro

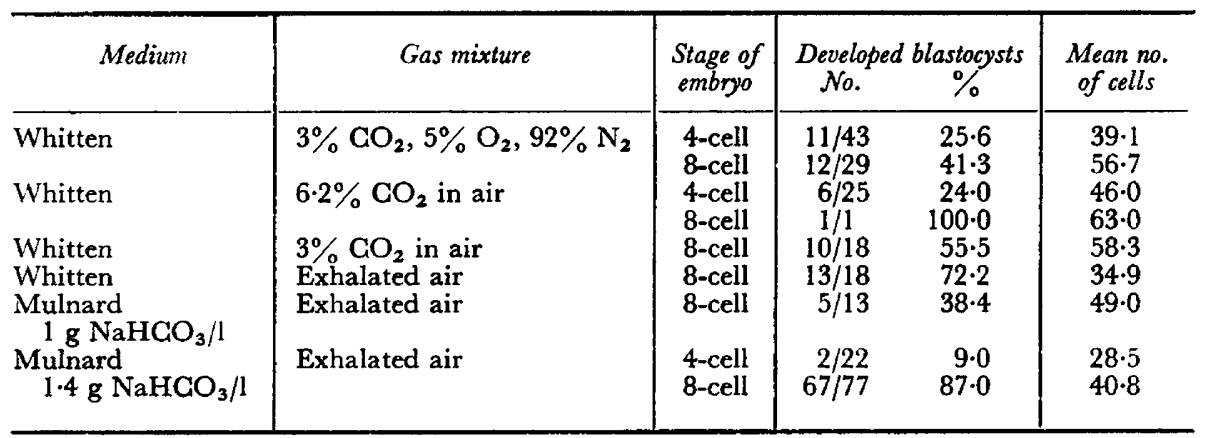

\section{Development in vitro}

The development of four- and eight-cell stages in various gas mixtures is shown in Table 3; one- and two-cell eggs underwent only one cleavage and were arrested in development. The best culture conditions for four-cell embryos were Whitten's medium and a gas mixture of $3 \% \mathrm{CO}_{2}, 5 \% \mathrm{O}_{2}$ and $92 \% \mathrm{~N}_{2}$; the blastocyst stage was reached about 110 to $120 \mathrm{hr}$ after the HCG injection. The eight-cell eggs developed to blastocysts in both media and under all the gas mixtures used, but the highest percentage of blastocysts was obtained in Mulnard's medium containing $1.4 \mathrm{~g} \mathrm{NaHCO}_{3} /$ litre and gassed with exhalated air. The blastocyst stage was reached 98 to $110 \mathrm{hr}$ after HCG injection, i.e. after 30 to $48 \mathrm{hr}$ of culture. Blastocysts developed in vitro had a slightly smaller cell number than those recovered from the uterus $96 \mathrm{hr}$ after HCG (40.0 cells compared to $49 \cdot 4$ ).

\section{DISCUSSION}

In the bank vole, ovulation can be induced by gonadotrophins (PMSG and 
HCG) and takes place $9 \frac{1}{2}$ to $11 \frac{1}{2} \mathrm{hr}$ after the administration of HCG, i.e. beginning and ending earlier than it would in a mouse. According to Edwards \& Gates (1959) and Marston \& Chang (1964), ovulation in the mouse begins 11 to $12 \mathrm{hr}$ after the administration of HCG and is completed by the 14th hr, although there is some variation according to strain (Edwards \& Gates, 1959). The bank vole colony used in this study was genetically diversified and this might have been expected to cause greater variability in the time of ovulation.

The number of ovulations following hormonal treatment is larger than that resulting from natural ovulations under field conditions or in the laboratory. According to Brambell \& Rowlands (1936), a female bank vole under field conditions produces a mean of 4.4 ova (1 to 12) at ovulation. Under laboratory conditions, the average litter size is 3.6 (Buchalczyk, 1970). Six females which ovulated spontaneously and were killed on the 4th day of pregnancy had an average of 3.6 eggs (E. Mystkowska, unpublished). The fact that over $50 \%$ of females ovulate 5 or more eggs ( 7.6 on average) after hormonal treatment indicates that superovulation can be obtained in voles, although not as easily as in mice in which an average of 24.6 (Fowler \& Edwards, 1957) or 21.4 (McLaren, 1962) eggs are produced after hormonal treatment.

According to Clarke et al. (1970), ovulation in the bank vole under laboratory conditions is evoked by mating and occurs 6 to $14 \mathrm{hr}$ after copulation. In the present experiments, it was not possible to exclude mating as an additional stimulus to cause ovulation; three of twelve females isolated from males and eight out of ninety-eight females kept with a male had no eggs in the oviducts after being treated with gonadotrophins.

The present study has shown that although development beyond implantation may occur after hormonally induced ovulation and mating, it takes place relatively rarely (four out of sixteen females). It is clear, moreover, that hormonally induced ovulation and mating do not automatically lead to pregnancy, since there were a few voles in which no eggs or only unfertilized eggs were found (twelve out of ninety-eight).

The rate of development of bank vole eggs in vivo was similar to that of mouse eggs.

The media in which the bank vole eggs were cultured were those suitable for development of mouse eggs. Although most of the eight-cell vole eggs developed to the blastocyst stage, only $25 \%$ of four-cell stages did so, probably because they were harvested just before the third cleavage. One- and two-cell eggs cleaved only once. A similar phenomenon was observed while working on the conditions under which mouse eggs can be cultured in vitro. It is known that the critical stage for development of one-cell mouse eggs in vitro is the period between the first and second cleavage, and that mouse eggs require specific energy sources at different stages of development and exactly defined $\mathrm{pH}$ and osmolarity conditions (Whitten, 1957; Whitten \& Biggers, 1968). The one-cell eggs develop only when pyruvate is added to the culture medium while the two-cell stage requires lactate. In the present study, the culture media contained both pyruvate and lactate but they did not support development of one- and twocell bank vole eggs. The rôles of other factors such as $\mathrm{pH}$ and osmolarity have still to be investigated. 


\section{ACKNOWLEDGMENTS}

The author wishes to express her thanks to Professor Z. Pucek and Mgr. A. Buchalczyk for making the animals from the Mammals Research Institute available to her.

The valuable advice of Professor A. K. Tarkowski in the course of the study is gratefully acknowledged.

\section{REFERENCES}

BRAmBelL, F. W. R. \& Rowlands, I. W. (1936) Reproduction of the bank vole (Evotomys glareolus, Schreber). Phil. Trans. R. Soc. B, 226, 71-97.

BRINSTER, R. L. (1963) A method for in vitro cultivation of mouse ova from two-cell to blastocyst. Expl Cell Res. 32, 205-208.

Buchalczyk, A. (1970) Reproduction, mortality and longevity of the bank vole under laboratory conditions. Acta theriol. 15, 153-176.

Clarke, J. R., Glulow, F. V. \& Grieg, F. (1970) Ovulation in the bank vole. J. Reprod. Fert. 23, 531, Abstr.

Edwards, R. G. \& Gates, A. H. (1959) Timing of the stages of the maturation divisions, ovulation, fertilization and the first cleavage of eggs of adult mice treated with gonadotrophins. F. Endocr. 18, 292-304.

Festing, M. (1971) International Index of Laboratory Animals. Medical Research Council Laboratory Animals Centre, Carshalton.

FowLER, R. E. \& EDWARDs, R. G. (1957) Induction of superovulation and pregnancy in mature mice by gonadotrophins. F. Endocr. 15, 374-384.

McLAREN, A. (1962) The relation between natural fecundity and response to follicle-stimulating hormone. F. Endocr. 25, 137-144.

Marston, J. H. \& Chang, M. C. (1964) The fertilizable life of ova and their morphology following delayed insemination in mature and immature mice. F. exp. Zool. 155, 237-252.

TARkowski, A. K. (1961) Mouse chimaeras developed from fused eggs. Nature, Lond. 190, 857-860.

TARKowski, A. K. (1966) An air-drying method for chromosome preparations from mouse eggs. Cytogenetics, 5, 394-400.

Whitren, W. K. (1957) Gulture of tubal ova. Nature, Lond. 179, 1081-1082.

WHITTEN, W. K. (1971) Nutrient requirements for the culture of preimplantation embryos in vitro. Adv. Biosci. 6, 129-139.

WhIrTEN, W. K. \& BiGGERs, J. D. (1968) Complete development in vitro of the pre-implantation stages of the mouse in a simple chemically defined medium. 7. Reprod. Fert. 17, 399-401. 